\title{
De impact van een uitzending van Radar
}

Op initiatief van Radar en het dagblad Trouw onderzochten 252 journalisten uit 36 landen de veiligheid van door de zorgautoriteiten goedgekeurde medische implantaten, waaronder de nervus vagus stimulator. In de uitzending van 26 november 2018 besteedde Radar aandacht aan vooral de negatieve aspecten van het gebruik van deze stimulator voor de behandeling van epilepsie. Louis Wagner was bij deze uitzending aanwezig; hier zijn relaas.

Radar beoogt consumentenzaken te onderzoeken in de breedste zin van het woord en misstanden te signaleren. In de uitzending van 26 november waren de medische implantaten aan de beurt, waaronder de nervus vagus stimulator. Nervus vagus stimulatie (NVS) is een behandeling die al ruim twintig jaar wordt toegepast bij patiënten met moeilijk behandelbare epilepsie. De berichtgeving van Radar over deze behandeling is, zo bleek tijdens de uitzending, weinig genuanceerd en nogal tendentieus.

\section{Voorbereiding op de uitzending}

Begin november werd ik uitgenodigd om in de uitzending iets over NVS te vertellen. Na uitvoerig intern beraad besloten we dat het zinvol was om aan de uitzending mee te werken zodat ik een reëel beeld over NVS zou kunnen schetsen. Wegblijven zou juist meer schade berokkenen. Ik bereidde me samen met de afdeling communicatie van Kempenhaeghe intensief voor en volgde een mediatraining. Tijdens deze mediatraining lag de nadruk op de kernboodschap dat NVS bij veel mensen met een moeilijk behandelbare, complexe vorm van epilepsie, na uitgebreide screening, een goede behandeling is die over het algemeen goed verdragen wordt.

\section{De uitzending}

Enkele dagen voor de uitzending ontving ik de vragen die gesteld konden worden. Die hadden vooral te maken met meldingen van bijwerkingen, calamiteiten en incidenten, en gingen verder over het ontbreken van veiligheidswaarschuwingen van de NVS-fabrikant op Nederlandse websites. Waarvan ik niet op de hoogte was, was dat door enkele interviews die werden uitgezonden de NVS-behandeling in een zeer kwalijk daglicht werd geplaatst. Deze video's kreeg ik pas een uur voor de uitzending te zien; ze gingen over bijwerkingen bij een Nederlandse patiënte en het uitblijven van effect bij haar, over asystolie door NVS bij een Amerikaanse patiënt en over veel doden onder NVS-patiënten, zoals de Amerikaanse journaliste Jeanne Lenzer met veel vertoon van drama vertelde. Ik kreeg niet de gelegenheid om inhoudelijk op deze video's te reageren, hier was geen ruimte voor. Ik kon mijn reactie pas geven toen het meldingssysteem werd besproken. Hoewel het laatste aspect in de uitzending goed uit de verf kwam, voelde ik me achteraf toch gefrustreerd. De nuances over NVS-behandeling, waar in de voorbereiding zo veel nadruk op lag, had ik niet kunnen overbrengen.

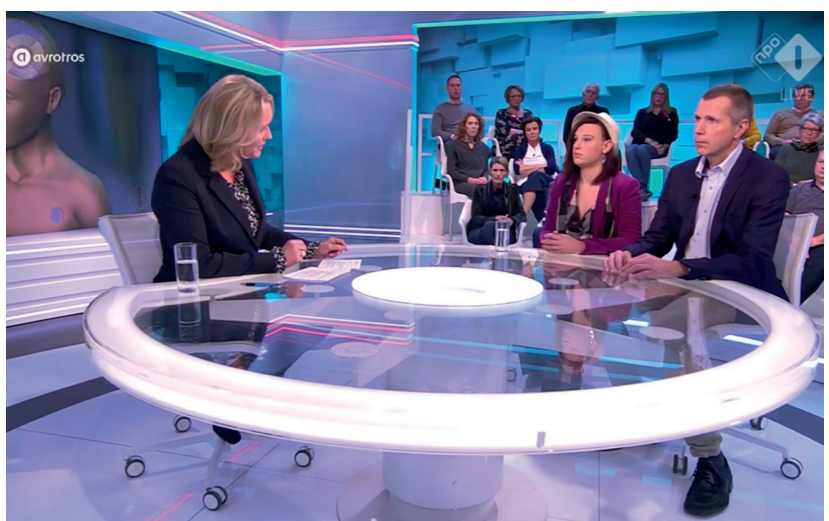

Na de uitzending

Door de uitzending ontstond er, zoals te verwachten, onrust bij patiënten en hun naasten. Als reactie op de berichten en telefoontjes van bezorgde ouders van patiënten met een NVS werd er een spoedberaad belegd waar werd besloten om op de websites van de epilepsiecentra en van de Epilepsie Vereniging Nederland (EVN) een bericht te plaatsen om de Radar-informatie te nuanceren. Er werd een bijeenkomst georganiseerd door de EVN en collega's van Kempenhaeghe, SEIN en het Universitair Medisch Centrum Utrecht om de bevindingen die in de Radar-uitzending aan de orde kwamen te bespreken en op basis van praktijkervaringen te nuanceren. Hiervoor hadden zich I50 personen aangemeld, waaruit bleek dat er behoefte was aan een dergelijke bijeenkomst. Hopelijk is de rust wat teruggekeerd in 'NVS-land'. En hopelijk heeft de negatieve berichtgeving er niet voor gezorgd, dat veel mensen willen stoppen met NVS (of niet willen ondergaan). Daarvoor is deze behandeling voor veel mensen te waardevol. 